\title{
The Role of Prophylactic Cranial Irradiation for Non-small Cell Lung Cancer
}

\author{
CRYSTALROSE PRECIVAL, MICKAYLA LANDY, CLAIRE POOLE and LAURA MULLANEY \\ Applied Radiation Therapy Trinity, Discipline of Radiation Therapy, Trinity College Dublin, Dublin, Ireland
}

\begin{abstract}
Background: The use of prophylactic cranial irradiation (PCI) to treat brain metastases (BM) in non-small cell lung cancer (NSCLC) is restricted due to the potential associated toxicity and lack of survival benefit. BM can have a negative impact on neurocognitive function $(N F)$ and quality of life (QOL). The aim of this review was to assess the impact of PCI on disease-specific and NF and QOL outcomes. Materials and Methods: An electronic database literature search was completed to identify relevant studies. Results: Fourteen published articles were included. PCI significantly reduced the incidence of $B M$, but no significant survival advantage was found. $N F$ decline was reported in one trial. No significant difference in QOL with PCI was reported. PCI was well tolerated by the majority of patients with NSCLC and associated with a relatively low toxicity. Conclusion: $P C I$ reduces the incidence of $B M$ without any significant survival advantage. PCI has the potential to be beneficial in practice for certain patients with locally advanced NSCLC, based on disease factors and patient preference.
\end{abstract}

Prophylactic cranial irradiation (PCI) is a technique that delivers radiation therapy (RT) to the whole brain to prevent the occurrence of brain metastases (BM) in aggressive cancer types that commonly metastasise to the brain (1). The rationale behind $\mathrm{PCI}$ is to eliminate undetectable micrometastases before they become clinically apparent (1).

This article is freely accessible online.

Correspondence to: Laura Mullaney, Discipline of Radiation Therapy, Trinity College Dublin, Trinity Building for Health Sciences, St James's Hospital Campus, Dublin 8, Ireland. Tel: +353 18963254, e-mail: laura.mullaney@tcd.ie

Key Words: Prophylactic cranial irradiation, non-small cell lung cancer, disease-free survival, overall survival, quality of life, neurocognitive function, review.
According to the American Cancer Society, about $85-95 \%$ of all lung cancer cases are non-small cell lung cancer (NSCLC) (2). The brain is the first site of metastases for up to $30 \%$ of these patients (3), with $60 \%$ of BM occurring in the first 6 months (4). With modern advances in the management of NSCLC, the risk of developing BM increases as survival is prolonged (5). The reported incidence of BM from NSCLC ranges from $17 \%$ to $54 \%$, with younger patients, those with locally advanced-stage disease, adenocarcinoma and large cell types at the higher end of this range of incidence $(4,6-9)$. BM are associated with high morbidity, poor prognosis (10) and neurocognitive and quality of life (QOL) deficits (10-12).

Patients with small cell lung cancer derive an overall (OS) and BM-free survival benefit from PCI (13). PCI for patients with NSCLC is not widely used due to the lack of established evidence for OS benefit and the potential for neurological toxicity post RT. PCI for NSCLC may not have an impact on OS or disease-free survival (DFS) but it has been shown to reduce the incidence of $\mathrm{BM}(11,14-19)$, therefore it is a matter of debate if these patients benefit from PCI.

Late cognitive toxicities are suggested to be associated with PCI and these may be a factor in the prescribing of this treatment. The Radiation Therapy Oncology Group trial (RTOG)-0214 reported a significant decline in memory at 1 year with PCI use (20). Neurocognitive function (NF) decline may occur as a direct result of vascular injury, demyelination or radionecrosis (20).

This review aimed to investigate published literature on the use of PCI in patients with NSCLC to assess the impact of PCI on disease-specific outcomes and report the effects of PCI on NF and QOL outcomes.

\section{Materials and Methods}

To ensure all appropriate studies were included in this review, a systematic approach was used for searching and selecting relevant publications. As the technique for treating PCI has remained relatively unchanged over the years, the start date of January 1980 
was selected. A primary search of the online databases of PubMed, Science Direct and EMBASE was carried out using the timeframe of January 1980 to Nov 2016. The following search terms and strategy were used:

(prophylactic cranial irradiation OR PCI OR cranial irradiation OR whole-brain radiation therapy OR WBRT)

AND (non small cell lung cancer OR NSCLC)

AND (brain metastases OR intracranial metastases OR brain secondaries) AND (toxicity OR neurocognitive function OR quality of life OR overall survival OR disease free survival OR median survival OR survival)

All publications identified from this search were assessed using the title and abstract for relevance based on the inclusion and exclusion criteria and duplicated publications were removed. Studies investigating all stages of NSCLC, all ages and performance status were included. Only articles reporting on randomised controlled trials (RCTs), nonrandomised prospective trials and retrospective studies were included. Different dose-fractionation schedules were also included. Studies investigating treatment for diagnosed BM, those not in English and those with an abstract only were excluded. A secondary search was conducted on the reference list of relevant articles to identify any additional literature. The data were extracted and tabulated for all eligible studies.

The outcomes measured were divided into disease-specific outcomes: incidence of BM (time-specific points and other), OS, DFS and median survival; and patient-related outcomes: NF and QOL. The QOL and NF assessment tools used in the studies varied widely.

\section{Results}

Fourteen articles $(n=1,838)$ were included in this review. The literature search identified six RCTs $(14-18,21,22)$ and six retrospective or non-randomised prospective trials investigating survival benefits and the incidence of BM of PCI in patients with $\operatorname{NSCLC}(7,8,11,16,19,23)$ (Table I). Five articles assessed the effects of PCI on NF and QOL $(11,12$, 16, 18, 20) (Table II). Gore et al. (14) and Sun et al. (20) both reported on analysis from the RTOG 0214 trial. The publication of the studies ranged from 1981 to 2014. The majority of articles used a prescription totalling $30 \mathrm{~Gy}$ to the whole brain $(n=10.71 \%)$, with the remainder using $20 \mathrm{~Gy}$ $(n=1), 36 \mathrm{~Gy}(\mathrm{n}=2)$ or $37.5 \mathrm{~Gy}(\mathrm{n}=1)(22)$.

Disease-related outcomes. All studies investigating the incidence of BM reported a decrease with the use of PCI and seven studies reported this decrease as being statistically significant $(11,14-18,22)$ (Table I). The greatest difference in the incidence rate of BM between PCI and observation was seen in the trial by Stuschke et al. (11) (incidence rate of BM at 4 years $13 \%$ vs. $54 \%$, respectively; $p=0.0004$ ).

Five out of the six RCTs reported a significant decrease in $\mathrm{BM}$ incidence $(14,15,17,18,22)$. A reduction in $\mathrm{BM}$ was seen following PCI in the Veterans Administration Lung Group (VALG) trial (6\% vs. 13\%; $p=0.038)(17)$ and the MD Anderson Cancer Center (MDACC) trial (4\% vs. 23\%; $p=0.002$ ) (15). These trials also reported on factors that affect outcomes of PCI, with multivariate analysis demonstrating a beneficial effect of PCI in patients with a good performance status and stage III diagnosis (15). The VALG trial identified that PCI was significantly more effective at reducing BM in patients with the adenocarcinoma subtype of NSCLC (17). Although no significant decrease in incidence was reported, the development of BM was shown to be delayed according to the RTOG 84-03 trial (21). The more recent RTOG-0214 trial (14) demonstrated a significant decrease in the risk of BM in patients with locally advanced NSCLC. Several other nonrandomised/retrospective studies demonstrated a significant benefit in a reduction of incidence of $\mathrm{BM}(11,16,19)$.

Four out of the six RTCs analysed survival benefit; three reported no significant survival advantage for PCI over observation $(14,17,18)$. Li et al. reported PCI significantly lengthened DFS when compared with the control group, with a median DFS of 28.5 versus 21.2 months (18). The VALG reported a median survival advantage for the observation group, 35.4 months, versus 41.4 months for those treated with PCI; this difference was not significant. The Southwest Oncology Group (SWOG) study was the only trial to report a significant reduction in medial survival with PCI treatment (8 vs. 11 months, $p=0.004$ ) (22). An MDACC trial reported the 3-year survival in the PCI-treated and control groups as $22 \%$ and $23.5 \%$, respectively, but no statistical analysis of this data was recorded (15). The largest RTC reported no significant increase in DFS for patients with NSCLC after PCI; DFS rates reported at 1 year were $56.4 \%$ and $51.2 \%$ for the PCI and observation arms, respectively $(p=0.11)(14)$. A retrospective review by Jacobs et al. also demonstrated no survival benefit with the use of PCI (19).

Neurocognitive function and quality of life. The most recent RTOG 0214 reported a significant decline in memory (immediate and delayed recall) at 1 year for patients treated with PCI, based on the Hopkins Verbal Learning Test (20). Gawkowska-Suwińska et al. investigated a group of 50 patients treated with PCI for NSCLC and reported a statistically significant decline in verbal IQ and visual-motor function pre and post PCI but no difference in NF (12). Pottgen et al. identified a slight decrease in NF for both the PCI-treated and the observation group when compared with a matched population (16) Stuschke et al. also identified impairments in attention and visual memory in all long-term survivors from NSCLC, not just the patients treated with PCI; these impairments did not interfere with daily life functioning (11).

Neuropsychology testing showed similar impairments in attention and visual memory in the PCI and non-PCI groups (11). Extensive NF testing was performed on 11 long-term survivors of NSCLC, with no statistically significant difference being found between patients (16). Magnetic resonance imaging (MRI) was performed on 10 of these 
patients; four patients presented with leukoencephalopathy (3 treated with PCI and one not treated with PCI, $p=0.2$ ) (16). Stuschke et al. also recorded higher grade white matter abnormalities in patients who received PCI compared with those who did not (11). The trial by Gawkowska-Suwińska et al. showed no significant changes in serum testosterone levels (Wilcoxon test; $p=0.062$ ) as an indicator of pituitary function following PCI, (12).

The RTOG 84-03 and MDACC trials did not specifically analyse NF and QOL but reported no late complications of PCI $(15,21)$, nor did the SWOG trial, which stated there was no excessive neurological toxicity with PCI although the definition of neurological toxicity was not reported (22).

The RTOG 0214 trial found no statistically significant difference at 6 or 12 months from baseline for any QOL components on the QLQ-C30 or QLQ-BN20 questionnaire for patients treated with PCI (20). Li et al. also reported that no significant differences were noted in deterioration rate for QOL and symptoms between the PCI and observation groups, as assessed by functional assessment of cancer therapy-lung (FACT-L) total score, FACT- L trial outcome index and FACT-lung cancer scale (18).

\section{Discussion}

Improvements in RT techniques and systemic treatments have resulted in improved survival for patients with NSCLC, however, the risk of developing BM increases as survival is prolonged, with the brain as the most frequent site of initial treatment failure $(5,24)$. This review shows that PCI can improve disease-related outcomes without significantly compromising NF and QOL. Seven out of the 10 trials that analysed BM incidence showed a significant reduction in BM following PCI $(11,14-18,22)$, with another reporting a borderline significant reduction (19). A challenge when comparing the published data on BM incidence was the lack of consistency in reporting time-specific endpoints. In a recent RCT, patients with stage IIIA-N2 NSCLC were assigned to observation or PCI. A significant reduction in the risk of BM following PCI at 5 years $(20.3 \%$ vs. $49.9 \%$; $p<0.001)$ was reported, however, this trial closed prematurely due to a low accrual rate (18) and results should be interpreted with caution. This low accrual may be linked to the inclusion criteria which selected patients with stage IIIA/B post radical treatment with stable disease or partial/completed response. Treatment had to be completed with 16 weeks of study enrolment. These criteria may have inadvertently led to selecting patients with a low risk of BM, as $60 \%$ of BM occur in the first 6 months after treatment (4) and may have resulted in a small sample population. The RTOG 0214 and MDACC trials demonstrated that PCI significantly reduced the risk of BM for patients with stage III when compared with earlier stages of disease $(14,15)$.
This is line with evidence that incidence of BM is more common in those with stage III (9) and node-positive N2-3 disease $(5,19,24)$, highlighting that PCI has a role in this cohort with locally advanced disease. Histology has also emerged as a factor for patient selection; PCI was more effective at reducing $\mathrm{BM}$ in patients with the adenocarcinoma subtype (17) when compares to those with squamous cell subtype; this is to be expected as BM are more common in the adenocarcinoma subtype.

The RTOG 84-03 trial was the only RCT not to demonstrate a significant reduction in the incidence of BM but it did identify a delay in the progression of $\mathrm{BM}$, favouring PCI (9\% vs. 19\%) (21). Based on the findings in this review it is clear that PCI can reduce the incidence of $\mathrm{BM}$ and it is reasonable to assume that this reduction may have a positive impact on patient QOL and morbidity.

According to the trials, there was no increase in OS for patients following PCI $(13,16,18,21,23)$. The only RCT to demonstrate any positive benefit from PCI was that by $\mathrm{Li}$ et al., where DFS was significantly lengthened with PCI when compared with the control group and the median OS was marginally but not significantly improved in the PCI arm (18). The other RCT that investigated DFS showed no significant increase in DFS for similar patients with stage III disease (14). There was a trend towards better DFS with PCI at 3 months but this may have been due to more patients developing BM in the observation arm at 1 year. Both of these recent studies closed early due to poor accrual, with half as many patients being assessed in the trial by Li et al. versus the RTOG trial, thus making it very difficult to draw a firm conclusion to the question of survival benefit. DFS should be an end-point in further trials to aid with future patient decision-making.

Only the SWOG trial demonstrated a significantly reduced median survival with PCI, however, unlike the other trials, PCI was administered concurrently with thoracic RT and it used the highest PCI dose (37.5 Gy/15 fractions). The resultant toxicity may have been a factor in this negative survival outcome. There are points of concern in all six RTCs. In the four older trials, the thoracic doses used would not be considered appropriate by current-day standards; this may have resulted in poor locoregional and extracranial control; also, in some cases, the trial was not correctly powered for the study aims. Current evidence-based multimodality treatment may improve local control, prolonging survival, and this may allow for the survival benefit of PCI to become apparent, however, the two most recent RCTs closed early due to poor accrual, leaving the question of survival benefit for current patients with NSCLC unanswered.

By the nature of this disease, those patients who had their BM controlled with PCI are the most likely group to present with relapse at another site as the presence of brain micrometastases is strongly associated with disseminated 
Table I. Incidence of brain metastasis (BM), median survival, outcomes and conclusions of the included studies.

\begin{tabular}{|c|c|c|c|c|c|}
\hline $\begin{array}{l}\text { Author, } \\
\text { Year, (Ref) }\end{array}$ & $\begin{array}{l}\text { Patients, } \\
\text { disease }\end{array}$ & Dose & $\begin{array}{l}\text { Incidence of BM } \\
\text { (PCI } v s . \text { no-PCI) }\end{array}$ & $\begin{array}{l}\text { Median survival } \\
\text { (PCI vs. no-PCI) }\end{array}$ & $\begin{array}{l}\text { Outcome/ } \\
\text { conclusion }\end{array}$ \\
\hline \multicolumn{6}{|c|}{ Randomised controlled trials } \\
\hline $\begin{array}{l}\text { RTOG } 0214 \text { Gore } \\
\text { et al. (2010) (14) }\end{array}$ & $\begin{array}{l}\mathrm{n}=340 \text {. Locally advanced } \\
\text { (stage III) }\end{array}$ & $\begin{array}{l}30 \mathrm{~Gy} / 15 \\
\mathrm{fr} / 3 \mathrm{w}\end{array}$ & $\begin{array}{c}7.7 \% \text { vs. } 18.0 \% \\
(p=0.004) \text { at } 1 \text { year }\end{array}$ & $\begin{array}{c}25.8 v s .24 .8 \\
\text { months }(p=0.86)\end{array}$ & $\begin{array}{l}\text { - Decrease in risk of BM } \\
\text { - No OS or DFS improvement } \\
\text { - Closed early due to low accrual }\end{array}$ \\
\hline $\begin{array}{l}\text { VALG trial Cox } \\
\text { et al. }(1981)(17)\end{array}$ & $\begin{array}{l}\mathrm{n}=281 . \text { Males, all lung } \\
\text { cell types }\end{array}$ & $\begin{array}{l}20 \mathrm{~Gy} / 10 \\
\mathrm{fr} / 2 \mathrm{w}\end{array}$ & $\begin{array}{c}6 \% \text { vs. } 13 \% \\
(p=0.038)\end{array}$ & $\begin{array}{c}35.4 \text { vs. } 41.4 \\
\text { months }(p=0.5)\end{array}$ & $\begin{array}{l}\text { PCI significantly reduced the } \\
\text { incidence of brain metastases, } \\
\text { with a greater benefit in the a } \\
\text { denocarcinoma subtype } \\
\text { - No significant improvement } \\
\text { in median survival }\end{array}$ \\
\hline $\begin{array}{l}\text { MDACC trial } \\
\text { Umsawasdi et al. } \\
(1984)(15)\end{array}$ & $\mathrm{n}=97$. Locally advanced & $\begin{array}{c}30 \mathrm{~Gy} / \\
10 \mathrm{fr} / 2 \mathrm{w}\end{array}$ & $\begin{array}{r}4 \% \text { vs. } 23 \% \\
(p=0.002)\end{array}$ & $\begin{array}{l}\text { 3-Year survival: } \\
22 \% \text { vs. } 23.5 \%\end{array}$ & $\begin{array}{l}\text { - Reduction in risk of BM } \\
\text { - No statistical analysis } \\
\text { of survival data } \\
\text { - Beneficial effects against BM } \\
\text { were significant in good } \\
\text { performance status, } \\
\text { squamous cell type }\end{array}$ \\
\hline $\begin{array}{l}\text { RTOG } 8403 \\
\text { Russell et al. } \\
(1991)(21)\end{array}$ & $\begin{array}{c}\mathrm{n}=187 . \text { Adenocarcinoma } \\
\text { and large cell }\end{array}$ & $\begin{array}{l}30 \mathrm{~Gy} / \\
10 \mathrm{fr} / 2 \mathrm{w}\end{array}$ & $\begin{array}{l}9 \% \text { vs. } 19 \% \\
(p=0.10)\end{array}$ & 8.4 vs. 8.1 months & $\begin{array}{l}\text { - No difference in OS } \\
\text { - No decrease in incidence of } \\
\text { BMs but their development } \\
\text { was delayed } \\
\text { - } \mathrm{n}=161 \text { inoperable }\end{array}$ \\
\hline $\begin{array}{l}\text { Li et al. } \\
(2014)(18)\end{array}$ & $\begin{array}{l}\mathrm{n}=156 \text { Resected } \\
\text { stage IIIA-N2 }\end{array}$ & $\begin{array}{l}30 \mathrm{~Gy} / \\
10 \mathrm{fr} / 2 \mathrm{w}\end{array}$ & $\begin{array}{c}20.3 \% \text { vs. } 49.9 \% \\
(\mathrm{p}<0.001) \text { at } 5 \text { years }\end{array}$ & $\begin{array}{c}31.2 \text { vs. } 27.4 \text { months } \\
(p=0.310)\end{array}$ & $\begin{array}{l}\text { - PCI significantly prolongs DFS } \\
\text { (PCI: } 28.5 \text { vs. Control: } 21.2 \\
\text { months) and significantly } \\
\text { decreases incidence of BM } \\
\text { - Main toxicities: headache, } \\
\text { nausea and fatigue } \\
\text { - Toxicities were mild } \\
\text { - Closed early due to low accrual }\end{array}$ \\
\hline $\begin{array}{l}\text { SWOG Miller } \\
\text { et al.(1998) (22) }\end{array}$ & $\mathrm{n}=254$ & $\begin{array}{c}37.5 \mathrm{~Gy} / 15 \\
\mathrm{fr} / 3 \mathrm{w}(\mathrm{n}=34) \\
30 \mathrm{~Gy} / 10 \mathrm{fr} / 2 \mathrm{w}\end{array}$ & $\begin{array}{c}1 \% \text { vs. } 11 \% \\
(p=0.003)\end{array}$ & $\begin{array}{l}8 v s .11 \text { months } \\
\quad(p=0.004)\end{array}$ & $\begin{array}{l}\text { - Significant reduction in } \\
\text { incidence of BM } \\
\text { - Significant reduction in median } \\
\text { survival with PCI } \\
\text { - No excessive neurological } \\
\text { toxicity with PCI observed } \\
\text { but the definition of neuro- } \\
\text { logical toxicity not stated }\end{array}$ \\
\hline
\end{tabular}

Retrospective and nonrandomised prospective trials

\begin{tabular}{|c|c|c|c|c|c|}
\hline $\begin{array}{l}\text { Jacobs et al. } \\
\text { (1987) (19) }\end{array}$ & $\begin{array}{c}\mathrm{n}=78 . \text { Stage II \& III } \\
\text { adenocarcinoma }\end{array}$ & $\begin{array}{l}30 \mathrm{~Gy} / \\
15 \mathrm{fr} / 3 \mathrm{w}\end{array}$ & $\begin{array}{c}5 \% \text { vs. } 24 \% \\
(p=0.06)\end{array}$ & $\begin{array}{c}17.4 \text { vs. } 16.9 \text { months } \\
(p=0.6)\end{array}$ & $\begin{array}{l}\text { - Reduction of BM with PCI } \\
\text { - Risk of developing BM is } \\
\text { significantly increased in } \\
\text { patients with N1 or N2 disease } \\
\text { - } \mathrm{n}=20 \text { received PCI }\end{array}$ \\
\hline $\begin{array}{l}\text { Stuschke et al. } \\
\text { (1999) (11) }\end{array}$ & $\begin{array}{l}\mathrm{n}=75 . \text { Locally } \\
\text { advanced }\end{array}$ & $\begin{array}{c}30 \mathrm{~Gy} / \\
15 \mathrm{fr} / 3 \mathrm{w}\end{array}$ & $\begin{array}{c}13 \% \text { vs. } 54 \% \\
(p=0.0004)\end{array}$ & Not reported & $\begin{array}{l}\text { - Higher grades of white matter } \\
\text { abnormalities with PCI } \\
\text { - PCI was especially beneficial } \\
\text { in a good-prognosis subgroup } \\
\text { (responders to induction chemo) } \\
\text { - Use of PCI supported }\end{array}$ \\
\hline $\begin{array}{l}\text { Skarin et al. } \\
\text { (1989) (23) }\end{array}$ & $\mathrm{n}=41$. Stage III & $\begin{array}{c}36 \mathrm{~Gy} / \\
18 \mathrm{fr} / 3.5 \mathrm{w}\end{array}$ & $14 \%$ vs. $26 \%$ & Not reported & $\begin{array}{l}\text { - } \mathrm{n}=7 \text { received PCI } \\
\text { - No further details provided } \\
\text { on PCI benefits }\end{array}$ \\
\hline
\end{tabular}


Table I. Continued

\begin{tabular}{|c|c|c|c|c|c|}
\hline $\begin{array}{l}\text { Author, } \\
\text { Year, (Ref) }\end{array}$ & $\begin{array}{l}\text { Patients, } \\
\text { disease }\end{array}$ & Dose & $\begin{array}{l}\text { Incidence of BM } \\
\text { (PCI vs. no-PCI) }\end{array}$ & $\begin{array}{l}\text { Median survival } \\
\text { (PCI vs. no-PCI) }\end{array}$ & $\begin{array}{l}\text { Outcome/ } \\
\text { conclusion }\end{array}$ \\
\hline $\begin{array}{l}\text { Strauss et al. } \\
(1992)(8)\end{array}$ & $\begin{array}{l}\mathrm{n}=41 . \text { Stage } \text { IIIa } \\
\text { non squamous }\end{array}$ & $\begin{array}{l}30 \mathrm{~Gy} / \\
15 \mathrm{fr} / 3 \mathrm{w}\end{array}$ & $0 \%$ vs. $12 \%$ & Not reported & $\begin{array}{l}\text { - } \mathrm{n}=13 \text { received PCI } \\
\text { - No further details provided } \\
\text { on PCI benefits }\end{array}$ \\
\hline $\begin{array}{l}\text { Albain et al. } \\
(1995)(7)\end{array}$ & $\begin{array}{c}\mathrm{n}=126 . \text { Stage } \\
\text { IIIA N2 }\end{array}$ & $\begin{array}{c}36 \mathrm{~Gy} / \\
18 \mathrm{fr} / 3.5 \mathrm{w}\end{array}$ & $\begin{array}{c}8 \% \text { vs. } 16 \% \\
(p=0.44)\end{array}$ & Not reported & $\begin{array}{l}\text { - } \mathrm{n}=18 \text { received PCI } \\
\text { - No further details provided } \\
\text { on PCI benefits }\end{array}$ \\
\hline $\begin{array}{l}\text { Pöttgen et al. } \\
\text { (2007) (16) }\end{array}$ & $\mathrm{n}=112$. Stage IIIA & $\begin{array}{c}30 \mathrm{~Gy} / \\
15 \mathrm{fr} / 3 \mathrm{w}\end{array}$ & $\begin{array}{c}9.1 \% \text { vs. } 27.2 \% \\
(p=0.04) \text { at } 5 \text { years }\end{array}$ & Not reported & $\begin{array}{l}\text { - PCI significantly reduced the } \\
\text { probability of BM as first site of } \\
\text { failure after tri-modality therapy } \\
\text { - No difference in toxicity } \\
\text { between arms } \\
\text { - Slight decreased in neuro- } \\
\text { cognition in both arms }\end{array}$ \\
\hline
\end{tabular}

n: Number of participants; PCI: prophylactic cranial irradiation; BM: brain metastases; fr: fractions; OS: overall survival; DFS: disease-free survival; w: week. Significance accepted at $p<0.05$.

Table II. Summary of quality of life $(Q O L)$ and neurological function $(N F)$ findings for the included studies.

\begin{tabular}{|c|c|c|c|c|}
\hline Author, Year, Ref & Population & Dose & $\begin{array}{l}\text { PCI impact on NF } \\
\text { with/without QOL }\end{array}$ & $\begin{array}{l}\text { Outcomes/ } \\
\text { conclusions }\end{array}$ \\
\hline \multicolumn{5}{|c|}{ Randomised controlled trials } \\
\hline $\begin{array}{l}\text { RTOG } 0214 \text { Sun } \\
\text { et al. }(2010)(20)\end{array}$ & $\begin{array}{l}\mathrm{n}=340 . \text { Locally } \\
\text { advanced (stage III) }\end{array}$ & $\begin{array}{l}30 \mathrm{~Gy} / \\
15 \mathrm{fr} / 3 \mathrm{w}\end{array}$ & $\begin{array}{l}\text { - Significant decline in memory } \\
\text { at } 1 \text { year for PCI patients } \\
\text { - No decrease in global cognitive } \\
\text { function or QOL at } 1 \text { year }\end{array}$ & $\begin{array}{l}\text { - Closed early with approximately a third } \\
\text { of the required patients enrolled. }\end{array}$ \\
\hline $\begin{array}{l}\text { Li } \text { et al. } \\
\text { (2014) (18) }\end{array}$ & $\begin{array}{l}\mathrm{n}=156 . \text { Resected } \\
\text { stage IIIA-N2 }\end{array}$ & $\begin{array}{l}30 \mathrm{~Gy} / \\
10 \mathrm{fr} / 2 \mathrm{w}\end{array}$ & $\begin{array}{l}\text { No significant differences were } \\
\text { noted in QOL and symptoms } \\
\text { between the two groups, as assessed } \\
\text { by FACT-L total score, FACT-L } \\
\text { TOI and the FACT- LCS. }\end{array}$ & $\begin{array}{l}\text { PCI acute toxicities included: headache } \\
\text { in } 27 \% \text {, nausea or vomiting in } 23 \% \text {, } \\
\text { fatigue in } 22 \% \text {, skin toxicity in } 5 \% \text { and } \\
\text { insomnia in } 2 \% \text {. The main late toxicities } \\
\text { of the brain included: mild headache } \\
\text { or slight lethargy }(22.2 \%) \text {, moderate } \\
\text { headache or great lethargy }(11.1 \%) \\
\text { and severe headaches }(2.5 \%)\end{array}$ \\
\hline
\end{tabular}

Retrospective and nonrandomised prospective trials

\begin{tabular}{|c|c|c|c|c|}
\hline $\begin{array}{l}\text { Pöttgen et al. } \\
\text { (2007) (16) }\end{array}$ & $\mathrm{n}=112$. Stage IIIA & $\begin{array}{l}30 \mathrm{~Gy} / \\
15 \mathrm{fr} / 3 \mathrm{w}\end{array}$ & $\begin{array}{l}\text { - No significant difference in NF } \\
\text { between the two groups }\end{array}$ & $\begin{array}{l}\text { - Results based on } 11 \text { long-term survivors } \\
\text { - Slight decreased neuro-cognition in both } \\
\text { the PCI and observation groups when } \\
\text { compared to normal population }\end{array}$ \\
\hline $\begin{array}{l}\text { Stuschke } \text { et al. } \\
\text { (1999) (11) }\end{array}$ & $\begin{array}{l}\mathrm{n}=75 . \text { Local } \\
\text { advanced }\end{array}$ & $\begin{array}{l}30 \mathrm{~Gy} / \\
15 \mathrm{fr} / 3 \mathrm{w}\end{array}$ & $\begin{array}{l}\text { - Neuropsychologic testing revealed } \\
\text { impairments in attention and visual } \\
\text { memory in long-term survivors } \\
\text { of both PCI and observation arms }\end{array}$ & $\begin{array}{l}\text { - Late toxicity to normal brain was } \\
\text { acceptable }\end{array}$ \\
\hline $\begin{array}{l}\text { Gawkowska- } \\
\text { Suwińska et al. } \\
(2014)(12)\end{array}$ & $\begin{array}{l}\mathrm{n}=50 . \text { Stage } \\
\text { II \& III }\end{array}$ & $\begin{array}{l}30 \mathrm{~Gy} / \\
15 \mathrm{fr} / 3 \mathrm{w}\end{array}$ & $\begin{array}{l}\text { - Slight but significant decrease in } \\
\text { Performance IQ with PCI } \\
\text { - No significant difference in NF from } \\
\text { the pre-PCI assessment }\end{array}$ & $\begin{array}{l}\text { - } 13 \% \text { Of patients reported late side effects } \\
\text { - Analysis of spectroscopic data showed } \\
\text { metabolic but reversible alterations } \\
\text { after PCI } \\
\text { - PCI was well tolerated and associated } \\
\text { with a relatively low toxicity }\end{array}$ \\
\hline
\end{tabular}

n: Number of participants; QOL: quality of life; NF: neurocognitive function; PCI: prophylactic cranial irradiation; fr:fractions; w: week; IQ: intelligence quotient; FACT- L: functional assessment of cancer therapy: lung; TOI: trial outcome index; LCS: lung cancer scale. 
disease. Therefore, the lack of OS benefit may be a result of uncontrolled disease in the thorax or extracranial metastases. This theory is supported by the MDACC trial (15), which found that 12 out of 14 control patients had $\mathrm{BM}$ as first site of relapse, while in the PCI-treated group, BM occurred only after failure at other sites, suggesting that if extracranial sites of relapse can be effectively managed then the development of BM could be delayed allowing the survival benefit of PCI to manifest itself. However, in the absence of an appropriately powered RCT, this cannot be proven.

As with all RT treatments, there is a risk of toxicity. PCI can be accompanied by early and late side-effects (25) which may have an impact on QOL. The potential negative effects on NF and QOL following PCI treatment are one argument against its use. However, BM can also cause a decline in NF and QOL, and lead to poorer prognosis $(10-12,26)$. Two trials reported no late complications from PCI $(15,21)$; another reported that late toxicity to the brain was acceptable (11) and a fourth stated the risk of NF decline was low (18). Testosterone level as an indicator of pituitary function were tested following PCI by one trial. This study was the first estimation of endocrine changes after PCI in the literature and no significant changes were found (12). Only two RCTs (RTOG 0214 and that by Li et al.) had set QOL and toxicity as study endpoints $(18,20)$. The RTOG 0214 reported no decrease in QOL at 6 or 12 months from baseline for patients treated with PCI $(p>0.5)(20)$. This finding was supported by the other RCT using different QOL assessment tools (18). It must be noted that both of these studies closed prior to their targeted accrual so their findings may not be fully validated. By comparison, QOL after PCI in small cell lung cancer also showed no significant difference in QOL for the PCI-treated and observation arms $(27,28)$.

Early delayed symptoms present typically 6 months or earlier after PCI and include somnolence syndrome, shortterm memory loss and acute leukoencephalopathy (29). Late delayed complications are of the greatest concern as they have the most impact on NF (29). PCI may cause toxicities that can lead to a decline in NF. Several studies have reported intellectual/NF impairment and abnormalities on brain computed tomography $(11,12,16,20)$ which were conceivably related to PCI but may also have been related to the other treatment modalities used.

The RTOG 0214 found a trend for greater decline in patient-reported cognitive functioning and a significant decline in memory (20). They also reported significantly worse NF for the PCI-treated arm at 3 months but not at the trial end point of 1 year. Other retrospective/nonrandomised trials provide mixed results, with two studies demonstrating that NF impairment was not exclusive to the PCI arm but also identified in the observation arm, suggesting that these changes are not a direct result of PCI alone $(11,16)$.

Three studies used MRI to evaluate physical changes to the brain following PCI and revealed white matter abnormalities of higher grades in patients who received PCI $(11,12,16)$. (16). Such damage to white matter is correlated with neurocognitive dysfunction (30), however, based on the RCTs in this review, this neurocognitive dysfunction only manifested as a significant memory loss in one study (20). The literature suggests NF decline is not exclusive to patients treated with PCI but is seen in all patients post multimodality treatment for NSCLC and that some of the initial NF changes are reversible over time.

With a shortened life-expectancy, QOL is an important consideration in decision-making; PCI has the potential to reduce QOL through toxicity following treatment. Li et al. reported acute toxicity rates ranging from insomnia in $2 \%$ of patients to $27 \%$ of patients reporting headache (18). PCI also results in alopecia. Alopecia can be psychologically damaging and lead to personal and social problems (31). Patients who suffered from alopecia after PCI had a median hair regrowth of 2.5 months (12). Interestingly, the main reason for patient refusal to participate in the GawkowskaSuwińska et al. study was fear of alopecia. A study of PCI for small cell lung cancer commented that decline in QOL was specifically linked to hair-loss and fatigue (32); therefore if PCI is implemented consideration of hair-loss and fatigue management should be areas of focus. Other late toxicities recorded include mild headache or slight lethargy $(22.2 \%)$, moderate headache or great lethargy $(11.1 \%)$ and severe headaches $(2.5 \%)$ (18). Proposed solutions to alleviate certain side-effects and further increase the tolerance of PCI include RT techniques that spare the inner ear, pituitary gland and hippocampus (12).

In the absence of a definitive answer from the trials included in this review, patient choice and shared decisionmaking play an important role. A discrete choice experiment by Lehman et al. found that $50 \%$ of patients with NSCLC, when making hypothetical choices regarding PCI, would accept PCI for no survival advantage long as there was no change in memory or ability to self-care (33). They also found that $90 \%$ of patients would accept PCI for a survival benefit of more than 6 months; $52 \%$ of patients pre-treatment (78\% post-treatment) would have accepted PCI with no survival benefit but for a reduction in BM. These results verify that although survival improvement is most important to patients, a reduction in $\mathrm{BM}$ incidence (especially after treatment) is important for a significant proportion of patients. Therefore, if patient preference is taken into account, they may choose PCI despite the lack of evidence for significant survival advantage.

Drawing firm conclusions from the data in this review was challenging due to the small number of trials, which often included a heterogeneous patient population, treatment regimes and PCI dose. In addition, some of the trials had low patient numbers and two RCTs closing prematurely due to poor accrual. 


\section{Conclusion}

PCI significantly reduces or delays the development of BM in patients with NSCLC; but does not provide any significant improvement in OS, and may cause memory loss. PCI was associated with relatively low toxicity with no decrease in QOL and was well tolerated by the majority of patients. An appropriately powered RCT with a high-risk patient population, homogenous primary treatments and PCI protocol is needed to provide a definitive answer regarding the role of PCI in patients with NSCLC. However, this review provides evidence that certain patients with locally advanced NSCLC are likely to benefit from PCI in terms of reduction of BM. PCI has the potential to be implemented in conjunction with modern local and systematic therapies, based on patient and disease factors, and in a shared decision-making setting.

\section{References}

1 Lee JJ, Bekele BN, Zhou X, Cantor SB, Komaki R and Lee JS: Decision analysis for prophylactic cranial irradiation for patients with small-cell lung cancer. J Clin Oncol 24(22): 3597-3603, 2006.

2 Cancer.Org. What is non-small cell lung cancer? Available from: https://www.cancer.org/cancer/non-small-cell-lung-cancer/ about/what-is-non-small-cell-lung-cancer.html

3 Lester JF, MacBeth FR and Coles B: Prophylactic cranial irradiation for preventing brain metastases in patients undergoing radical treatment for non-small-cell lung cancer: A cochrane review. Int J Radiat Oncol Biol Phys 63(3): 690-694, 2005.

4 Gaspar LE, Chansky K, Albain KS, Vallieres E, Rusch V, Crowley JJ, Livingston RB and Gandara DR: Time from treatment to subsequent diagnosis of brain metastases in stage III non-small-cell lung cancer: A retrospective review by the southwest oncology group. J Clin Oncol 23(13): 2955-2961, 2005.

5 Cox JD, Scott CB, Byhardt RW, Emami B, Russell AH, Fu KK, Parliament MB, Komaki R and Gaspar LE: Addition of chemotherapy to radiation therapy alters failure patterns by cell type within non-small cell carcinoma of lung: Analysis of radiation therapy oncology group (RTOG) trials. Int J Radiat Oncol Biol Phys 43(3): 505-509, 1999.

6 Arriagada R, Le Chevalier T, Quoix E, Ruffie P, de Cremoux H, Douillard J, Tarayre M, Pignon J and Laplanche A: ASTRO (american society for therapeutic radiology and oncology) plenary: Effect of chemotherapy on locally advanced non-small cell lung carcinoma: A randomized study of 353 patients. GETCB (groupe d'etude et traitement des cancers bronchiques), FNCLCC (féderation nationale des centres de lutte contre le cancer) and the cebi trialists. Int J Radiat Oncol Biol Phys 20(6): 1183-1190, 1991.

7 Albain KS, Rusch VW, Crowley JJ, Rice TW, Turrisi 3rd A, Weick JK, Lonchyna VA, Presant CA, McKenna RJ and Gandara DR: Concurrent cisplatin/etoposide plus chest radiotherapy followed by surgery for stages IIIa (n2) and IIIb non-small-cell lung cancer: Mature results of southwest oncology group phase ii study 8805. J Clin Oncol 13(8): 1880-1892, 1995.
8 Strauss GM, Herndon J, Sherman D, Mathisen D, Carey R, Choi $\mathrm{N}$, Rege V, Modeas C and Green M: Neoadjuvant chemotherapy and radiotherapy followed by surgery in stage IIIa non-smallcell carcinoma of the lung: Report of a Cancer and Leukemia Group B phase II study. J Clin Oncol 10(8): 1237-1244, 1992.

9 Salbeck R, Grau HC and Artmann H: Cerebral tumor staging in patients with bronchial carcinoma by computed tomography. Cancer 66(9): 2007-2011, 1990.

10 Hanibuchi M, Kim S-J, Fidler IJ and Nishioka Y: The molecular biology of lung cancer brain metastasis: An overview of current comprehensions and future perspectives. J Med Invest 61(3.4): 241-253, 2014

11 Stuschke M, Eberhardt W, Pottgen C, Stamatis G, Wilke H, Stuben G, Stoblen F, Wilhelm H, Menker H and Teschler H: Prophylactic cranial irradiation in locally advanced non-smallcell lung cancer after multimodality treatment: Long-term follow-up and investigations of late neuropsychologic effects. J Clin Oncol 17(9): 2700-2700, 1999.

12 Gawkowska-Suwińska M, Blamek S, Heyda A, Boguszewicz Ł, Cichoń A, Zarudzki Ł, Nowicka E, Behrendt K, SmolskaCiszewska B and Plewicki G: Tolerability and toxicity of prophylactic cranial irradiation in patients with non-small cell lung cancer-results of a phase II study (with estimation of hematological toxicity, pituitary function and magnetic resonance spectra changes). Rep Pract Oncol Radiother 19(6): 361-368, 2014.

13 Prophylactic Cranial Irradiation Overview Collaborative Group: Cranial irradiation for preventing brain metastases of small cell lung cancer in patients in complete remission. Cochrane Database Syst Rev 4: CD002805, 2000.

14 Gore EM, Bae K, Wong SJ, Sun A, Bonner JA, Schild SE, Gaspar LE, Bogart JA, Werner-Wasik M and Choy H: Phase III comparison of prophylactic cranial irradiation versus observation in patients with locally advanced non-small-cell lung cancer: Primary analysis of radiation therapy oncology group study RTOG 0214. J Clin Oncol 29(3): 272-278, 2010.

15 T, Valdivieso M, Chen TT, Barkley HT, Booser DJ, Chiuten DF, Dhingra HM, Murphy WK, Dixon CL and Farha P: Role of elective brain irradiation during combined chemoradiotherapy for limited disease non-small cell lung cancer. J Neurooncol 2(3): 253-259, 1984.

16 Pöttgen C, Eberhardt W, Grannass A, Korfee S, Stüben G, Teschler H, Stamatis G, Wagner H, Passlick B and Petersen V: Prophylactic cranial irradiation in operable stage IIIa non-smallcell lung cancer treated with neoadjuvant chemoradiotherapy: Results from a German multicenter randomized trial. J Clin Oncol 25(31): 4987-4992, 2007.

17 Cox JD, Stanley K, Petrovich Z, Paig C and Yesner R: Cranial irradiation in cancer of the lung of all cell types. Jama 245(5): 469-472, 1981.

18 Li N, Zeng Z-F, Wang S-Y, Ou W, Ye X, Li J, He X-H, Zhang B-B, Yang $\mathrm{H}$ and Sun H-B: Randomized phase III trial of prophylactic cranial irradiation versus observation in patients with fully resected stage IIIa-N2 non small-cell lung cancer and high risk of cerebral metastases after adjuvant chemotherapy. Ann Oncol 26(3): 504-509, 2014.

19 Jacobs RH, Awan A, Bitran JD, Hoffman PC, Little AG, Ferguson MK, Weichselbaum R and Golomb HM: Prophylactic cranial irradiation in adenocarcinoma of the lung a possible role. Cancer 59(12): 2016-2019, 1987. 
20 Sun A, Bae K, Gore EM, Movsas B, Wong SJ, Meyers CA, Bonner JA, Schild SE, Gaspar LE and Bogart JA: Phase III trial of prophylactic cranial irradiation compared with observation in patients with locally advanced non-small-cell lung cancer: Neurocognitive and quality-of-life analysis. J Clin Oncol 29(3): 279-286, 2010.

21 Russell A, Pajak T, Selim H, Paradelo J, Murray K, Bansal P, Cooper J, Silverman S and Clement J: Prophylactic cranial irradiation for lung cancer patients at high risk for development of cerebral metastasis: Results of a prospective randomized trial conducted by the Radiation Therapy Oncology Group. Int J Radiat Oncol Biol Phys 21(3): 637-643, 1991.

22 Miller T, Crowley J, Mira J, Schwartz J, Hutchins L and Baker $\mathrm{L}$ : A randomized trial of chemotherapy and radiotherapy for stage III non-small cell lung cancer. Cancer Ther 1: 229-236, 1998.

23 Skarin A, Jochelson M, Sheldon T, Malcolm A, Oliynyk P, Overholt R, Hunt $M$ and Frei E: Neoadjuvant chemotherapy in marginally resectable stage III N0 non-small cell lung cancer: Long-term follow-up in 41 patients. J Surg Oncol 40(4): 266274, 1989.

24 Komaki R, Scott CB, Byhardt R, Emami B, Asbell SO, Russell AH, Roach M, Parliament MB and Gaspar LE: Failure patterns by prognostic group determined by recursive partitioning analysis of 1547 patients on four Radiation Therapy Oncology Group (RTOG) studies in inoperable nonsmall-cell lung cancer. Int J Radiat Oncol Biol Phys 42(2): 263-267, 1998.

25 Giordano FA, Welzel G, Abo-Madyan Y and Wenz F: Potential toxicities of prophylactic cranial irradiation. Transl Lung Cancer Res 1(4): 254-262, 2012.

26 Nussbaum ES, Djalilian HR, Cho KH and Hall WA: Brain metastases: Histology, multiplicity, surgery, and survival. Cancer 78(8): 1781-1788, 1996.

27 Wolfson AH, Bae K, Komaki R, Meyers C, Movsas B, Le Pechoux C, Werner-Wasik M, Videtic GM, Garces YI and Choy $\mathrm{H}$ : Primary analysis of a phase II randomized trial radiation therapy oncology group 0212: Impact of different total doses and schedules of prophylactic cranial irradiation on chronic neurotoxicity and quality of life for patients with limited-disease small-cell lung cancer. Int J Radiat Oncol Biol Phys 81(1): 7784, 2011.
28 Gregor A, Cull A, Stephens R, Kirkpatrick J, Yarnold J, Girling D, Macbeth F, Stout R, Machin D and for Cancer UKCC: Prophylactic cranial irradiation is indicated following complete response to induction therapy in small cell lung cancer: Results of a multicentre randomised trial. Eur J Cancer 33(11): 17521758, 1997.

29 Tofilon PJ and Fike JR: The radioresponse of the central nervous system: A dynamic process. Radiat Res 153(4): 357-370, 2000.

30 Breteler MM, van Amerongen NM, van Swieten JC, Claus JJ, Grobbee DE, van Gijn J, Hofman A and van Harskamp F: Cognitive correlates of ventricular enlargement and cerebral white matter lesions on magnetic resonance imaging. The rotterdam study. Stroke 25(6): 1109-1115, 1994.

31 Hunt $\mathrm{N}$ and McHale S: The psychological impact of alopecia. BMJ 331(7522): 951, 2005.

32 Slotman BJ, Mauer ME, Bottomley A, Faivre-Finn C, Kramer GW, Rankin EM, Snee M, Hatton M, Postmus PE and Collette L: Prophylactic cranial irradiation in extensive disease small-cell lung cancer: Short-term health-related quality of life and patient reported symptoms - results of an international phase iii randomized controlled trial by the EORTC radiation oncology and lung cancer groups. J Clin Oncol 27(1): 78-84, 2009.

33 Lehman M, Gorayski P, Watson S, Edeling D, Jackson J and Whitty J: Patient preferences regarding prophylactic cranial irradiation: A discrete choice experiment. Radiother Oncol 121(2): 225-231, 2016. 